\title{
Ethical Awareness: Genetic Modification and Economic Development?
}

\author{
Carolyn Ashe \\ University of Houston-Downtown
}

This paper presents moral arguments on whether genetic modification should be used to further economic development. Genetic Modification is a powerful tool used by trade and industry to develop products that increase production, saves lives, and increase quality of life. There are moral issues and concerns with genetic modifications; do the benefits outweigh the risks and do the ends justify the means?

\section{INTRODUCTION}

Genetic modification is currently a hot topic in regards to trade and industry expansion. Genetic modification is used in everything from crops and livestock to diseases and cures. There are moral arguments to be made, both for and against genetic modification of organisms. The moral debate that surrounds genetic modification is between the pursuit of genetic modification and economic development.

\section{WHAT IS GENETIC MODIFICATION}

Genetic modification uses technology to add, subtract, or change the DNA of an organism. Genetic modification, also known as genetic engineering, has been performed since 1972 to combine viruses (Jackson, Symons, \& Berg, 1972). Genetic modification has been used in trade and industry modify cells to produce insulin, plants to resist insects, drought, and herbicides, and livestock to produce disease resistant animals. Genetic modification is used in research; by inserting foreign DNA into well studied bacteria or lab animals, researchers are able to study the effects of said DNA. Genetic modification has powerful applications and therefore causes moral concern to those worried about the future consequences that it may bring along.

\section{ARGUMENTS FOR GENETIC MODIFICATION}

Genetic Modification has produced several lifesaving products that have increased the lifespan and quality of life of humans. Pharmaceutical companies have used genetic modification to mass produce insulin, human growth hormones, vaccines, and more (Avise, 2004). In industry, genetic modification has created bacteria that can eat oil to clean up oil spills (National Geographic, 2011) and bacteria to produce ethanol (Dien, Cotta.T, \& Jeffries, 2003). In agriculture, plants are engineered to resist fungus, virus, insects, droughts, and herbicides (Avise, 2004). There are moral arguments to be made in favor of genetic modification. 


\section{Economic Value Orientation}

Corporations are beholden to shareholders and therefore duty bound to create wealth. The moral philosophy of economic value orientation supports the outcomes of genetic modification; genetic modification has produced goods that return value in the form of monetary gain (Ferrell, Fraedrich, \& Ferrell, 2017). Biotechnology companies have grown (see Figure 1) from $\$ 93$ billion in 2006 to $\$ 157$ billion in 2011 (FAZ, 2012). Patents for genetically engineered drugs have nearly tripled from 432 in 1990 to 1228 in 2010 (VFA - Statistics, 2011). The percentage of US crops that are genetically modified has grown from an average of 11\% to 87.5\% from 1997 to 2015 (US Department of Agriculture, 2015). Genetically modified goods have provided an incredible return on investment for investors.

\section{FIGURE 1 \\ ECONOMIC VALUE ORIENTATION FOR GENETIC MODIFICATION: BIOTECHNOLOGY REVENUE}

\section{Total biopharmaceutical revenue worldwide from 2006 to 2011 (in billion U.S. dollars)}

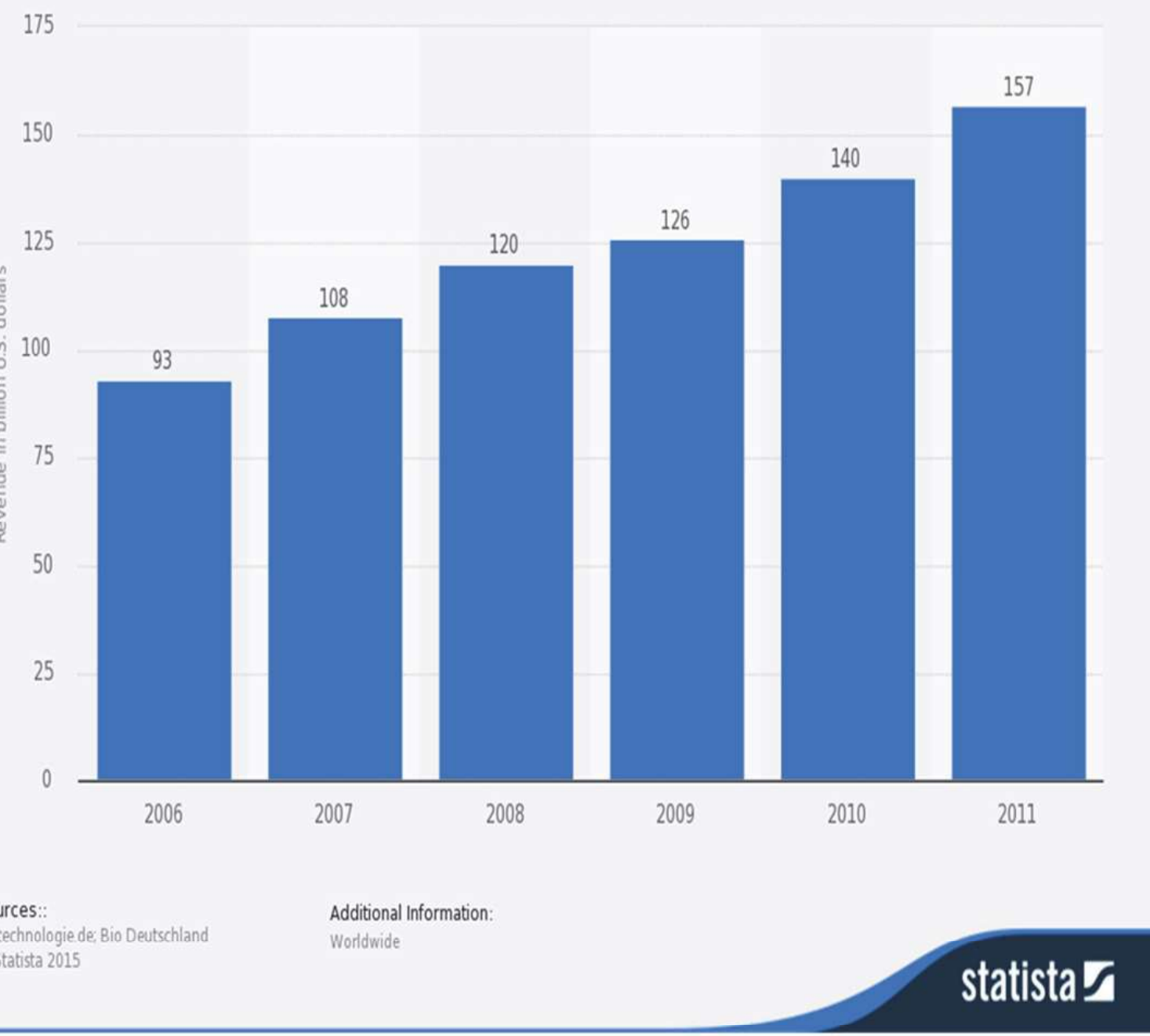

(FAZ, 2012) 


\section{Goodness Theories}

The end result of genetic modification are products that saves and enhances lives. The goodness theories typically focus on the end result of actions and the goodness or happiness created by them (Ferrell, Fraedrich, \& Ferrell, 2017). "Millions and countless lives" are saved by insulin produced by genetically modified bacteria (American Diabetes Association, 2012). Norman Borlaug is said to have saved a "billion lives" genetically modifying wheat to resist pests and disease; his "miracle wheat" ended famine (Biello, 2009). If lives saved equates to goodness and the lives extended equates to happiness, then genetic modification is justified under the goodness theories.

\section{Enlightened Egoist Theory}

If ecological impact is important to the well-being of others, then long-term, genetic modification has led to crops and livestock leaving a smaller impact on our planet. The enlightened egoist theory "takes a long term perspective and allows for the well-being of others" (Ferrell, Fraedrich, \& Ferrell, 2017); the impact of actions on the ecosystem can take many years to reveal themselves. Genetically modified plants produce more per acre and are resistant to pests, disease, and drought (Biello, 2009); therefore, farmers can use less land and less water to produce more crops. Livestock grown on feed instead of grazing on grass "shortens the amount of time it takes to raise cattle", results in less water consumed, and less methane produced by livestock (Profita, 2012).

\section{Utilitarian Approach}

Philanthropists like Bill Gates are taking a utilitarian approach with genetic modification. The billionaire is funding the research of genetically modified mosquitoes that are immune to malaria (Cheng, 2015). Malaria kills over one million people a year, mostly children, and is most readily transmitted by mosquitoes (UNICEF, 2015). The utilitarian views that the lives saved by the genetically modified mosquitoes outweigh possible consequences; malaria may become even more deadly as it struggles to find a path to survive.

\section{ARGUMENTS AGAINST GENETIC MODIFICATION}

Genetic modification fundamentally changes the DNA of an organism - it is no longer its original self. The moral arguments against genetic modification are that genetic modification of organisms are unnatural and the long term effects of genetic modification are yet unknown. The benefits of genetic modification must be carefully weighed against the moral principles.

There has been backlash against genetically modified products. Large international trade and industry conferences that cater to genetically modified producers are protested (Associated Press, 2013). Some businesses advertise that they are GMO (genetically modified organism) free to distinguish themselves (Mosbergen, 2015). Consumers worry about the unknown health effects that may be caused by GMO products (Palmer, 2013) and the ecological impacts caused by them (Ormandy, Dale, \& Griffin, 2011).

\section{Idealism}

Idealism of innate rights argues against speciesism; that one species is greater than another. Animal rights activists are concerned with an animal's well-being; animals cannot consent to experimentation. GMO products must be tested on animals before human use and livestock themselves have been subject to genetic modification testing to create new breeds. Genetic modification of animals is essentially medical experimentation; the sentience of primates and herd animals cause concern to animal rights activists.

\section{Instrumentalists}

Though the end product of GMOs saves lives and increases the quality of life, instrumentalists argue that the means to produce such products are not just. GMO seed producers have developed crops that increase production but will not produce viable seeds to produce more crops (Associated Press, 2013); the 
farmer must always buy more seeds from the seed producer. The ecological impact of such seeds is yet unknown, anti-GMO protestors argue that such seeds could weaken natural selection (Associated Press, 2013); introducing an unnatural element into the ecosystem causes unknown changes. GMO plants and livestock produced to resist disease may feed more people, however these resistances may create even stronger strains of disease through natural selection (Palmer, 2013).

\section{Deontology}

Those who believe the claims that GMO products cause adverse effects in humans protest with a deontological point of view (see Figure 2). In the United States, there are no regulations requiring trade and industry from labeling products containing GMOs (Dokoupil, 2015). Trade and industry's pursuit of profit should not outweigh the right of the individual to know what is in their products and how it was produced. The rights of independent farmers against those of monopolies should also be weighed when discussing GMOs. The use of GMO in plants and livestock have increased dramatically from 1997 to 2015 (US Department of Agriculture, 2015); it is becoming increasingly difficult for independent farmers to compete, they do not have the resources to perpetually buy GMO seeds.

\section{FIGURE 2 \\ DEONTOLOGICAL VIEW AGAINST GENETIC MODIFICATION: LABELING OF GMOS}

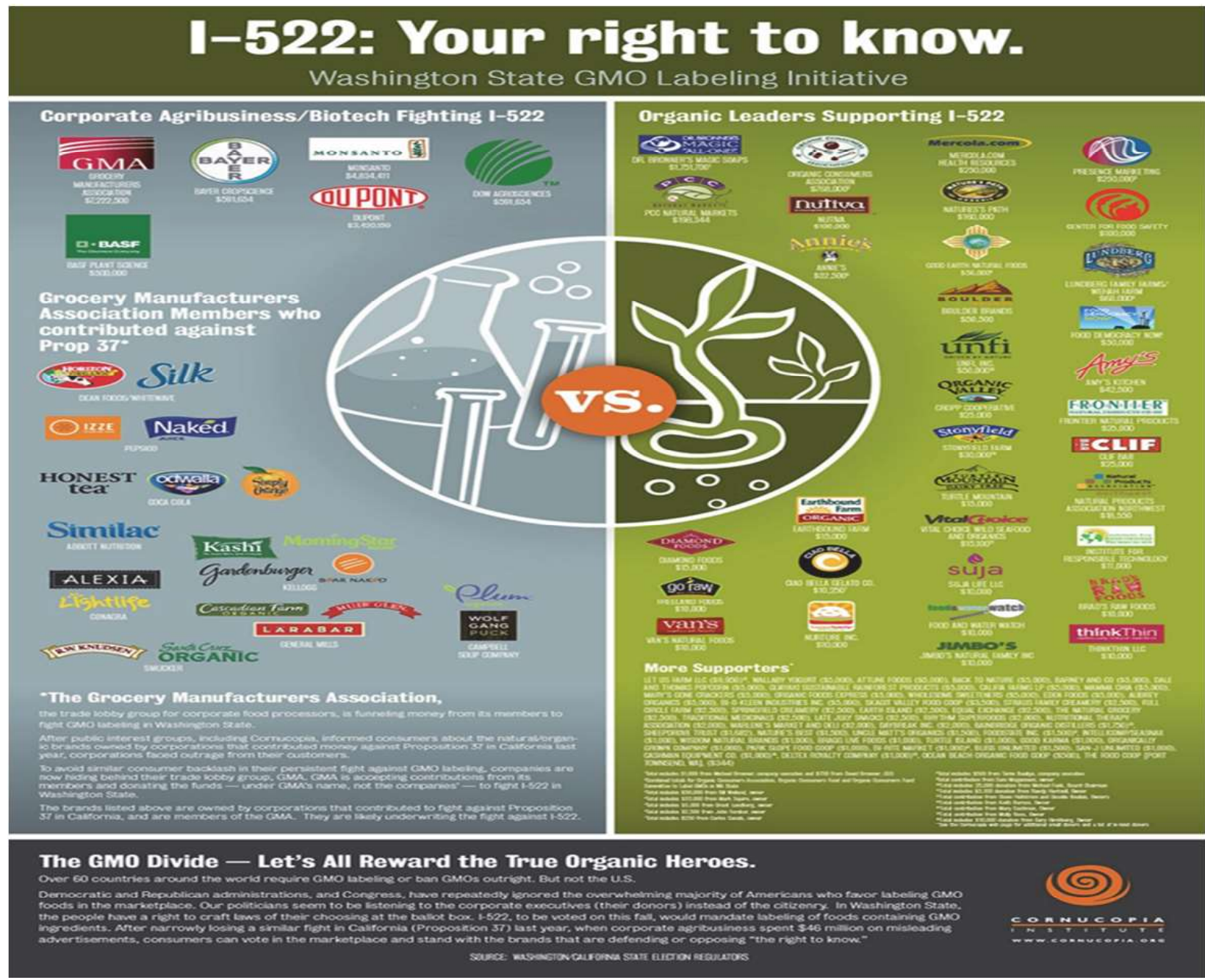

(Cornucopia Institute, 2013) 


\section{Meta-ethical Relativistic View}

Although there are many GMO products scientifically determined to be safe for consumption, this will not sway those with a meta-ethical relativistic view. Rumors of unsafe grain produced by Monsanto caused a panic among pregnant women (Associated Press, 2013); this however was proven to be unfounded. GMO protestors often mention the dangers of "messing with DNA" (MarkH, 2013); they incorrectly link that the consumption of GMO products will transfer the modified DNA to humans.

\section{CONCLUSION}

Recently, a study conducted at the University at Buffalo revealed a future breakthrough demonstrating that adult skin cells can be converted into neural crest cells (a type of stem cell) without any genetic modification. These stem cells can yield other cells that are present in the spinal cord and the brain (University at Buffalo, ScienceDaily, 2017).

FIGURE 3

\section{FOR OR AGAINST: PUTTING IT ALL TOGETHER}

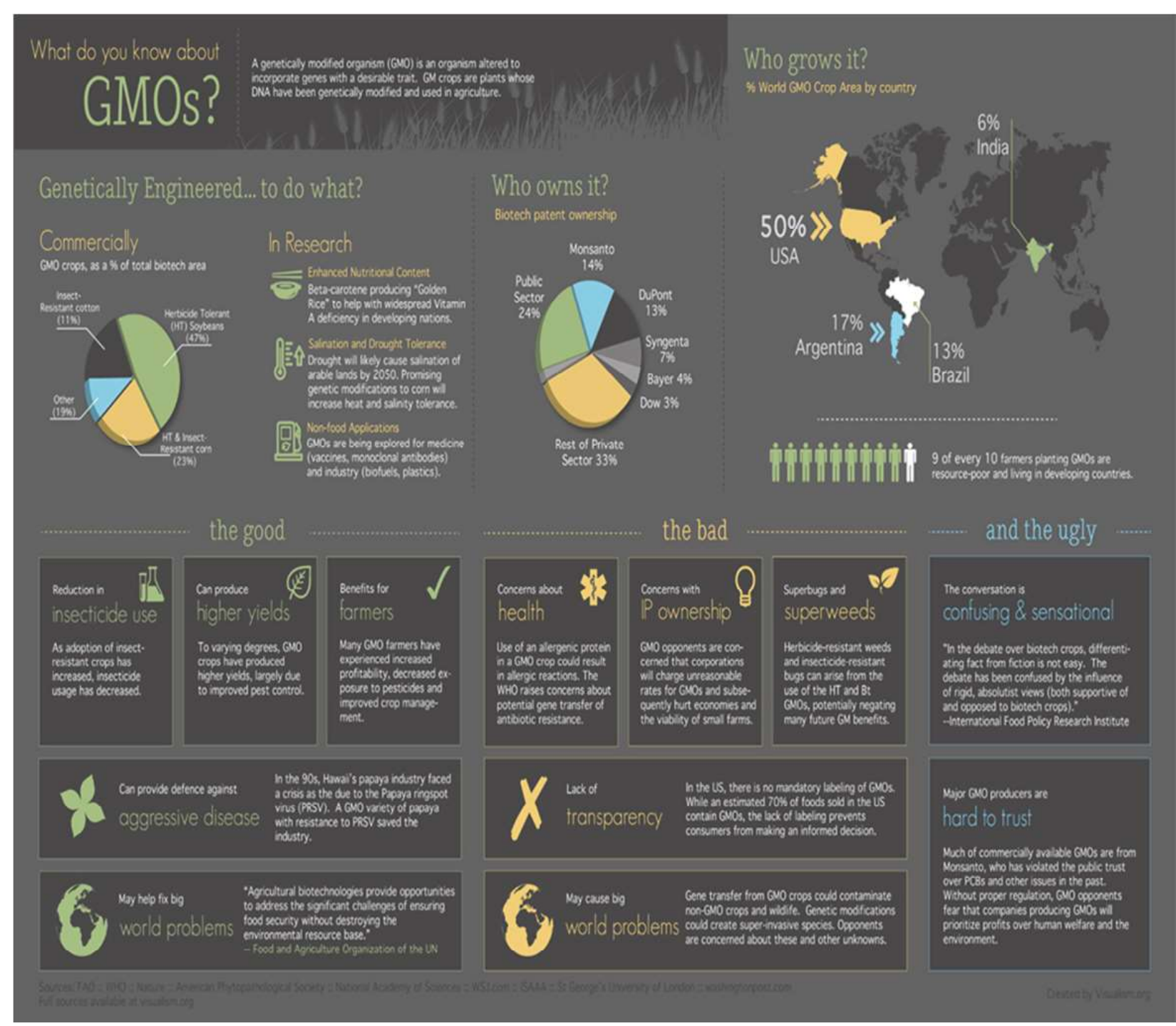

(KALINDQUIST, 2012) 
There are moral arguments to be made both for and against genetic modification of organisms. Genetic modification is a powerful tool for trade and industry to research and develop products that can increase production, save lives, and enhance the quality of life (see Figure 3). However, because it affects the natural process, it is yet unknown what implications it may produce in the future.

\section{REFERENCES}

American Diabetes Association. (2012, August 12). The History of a Wonderful Thing We Call Insulin. Retrieved from American Diabetes Association: http://diabetesstopshere.org/2012/08/21/thehistory-of-a-wonderful-thing-we-call-insulin/

Associated Press. (2013, May 25). 'March Against Monsanto' Protesters Rally Against U.S. Seed Giant And GMO Products. Retrieved from Huffington Post:

http://www.huffingtonpost.com/2013/05/25/march-against-monsanto-gmoprotest_n_3336627.html

Avise, J. C. (2004). The hope, hype \& reality of genetic engineering: remarkable stories from agriculture, industry, medicine, and the environment. US: Oxford University Press.

Biello, D. (2009, Sept 14). Norman Borlaug: Wheat breeder who averted famine with a "Green Revolution". Retrieved from Scientic American: http://blogs.scientificamerican.com/newsblog/norman-borlaug-wheat-breeder-who-av-2009-09-14/

Cheng, M. (2015, Nov 19). Will genetically modified mosquitoes stop malaria's spread? Retrieved from ABC News: http://abcnews.go.com/Technology/story?id=5211497\&page=1

Cornucopia Institute. (2013, Sept 24). I-522 Your Right to Know. Retrieved from Cornucopia.com: http://www.cornucopia.org/wp-content/uploads/2013/09/I-522-full.jpg

Dien, B. S., Cotta.T, M. A., \& Jeffries, W. (2003). Bacteria engineered for fuel ethanol production: current status. Appl Microbiol Biotechnol, 258-266.

Dokoupil, T. (2015, Jul 29). Why Congress is having a food fight over GMO labeling. Retrieved from MSNBC: http://www.msnbc.com/msnbc/why-congress-having-food-fight-over-gmo-labeling

FAZ. (2012). Total biopharmaceutical revenue worldwide from 2006 to 2011 (in billion U.S. dollars). Frankfurt: Frankfurter Allgemeine Zeitung.

Ferrell, Fraedrich, \& Ferrell. (2017). Chapter 6: Individual Factors: Moral Philosphies and Values. In Ferrell, Fraedrich, \& Ferrell, Business Ethics: Ethical Decision Making and Cases (p. PPT). Boston: Cengage Learning.

Goeddel, D., Kleid, D. G., Bolivar, F., Heyneker, H. L., Yansura, D. G., Crea, R., . . Riggs, A. D. (1979). Expression in Escherichia coli of chemically synthesized genes for human insulin. PNAS, 106-110.

Jackson, D., Symons, R., \& Berg, P. (1972). Biochemical Method for Inserting New Genetic Information into DNA of Simian Virus 40: Circular SV40 DNA Molecules Containing Lambda Phage Genes and the Galactose Operon of Escherichia coli. PNAS, 2904-2909.

KALINDQUIST. (2012, Nov 25). What do you know about GMOs? Retrieved from VISUALISM:Food \& Wellness, Visualized: http://visualism.org/2012/11/25/what-do-you-know-about-gmosinfographic/

MarkH (2013, Mar 29). Anti-GMO writers show profound ignorance of basic biology and now Jane Goodall has joined their ranks. Retrieved from ScienceBlogs:

http://scienceblogs.com/denialism/2013/03/29/anti-gmo-writers-show-profound-ignorance-ofbasic-biology-and-now-jane-goodall-has-joined-their-ranks/

Mosbergen, D. (2015, Apr 27). Chipotle Becomes First Major Restaurant Chain To Serve Only GMOFree Food. Retrieved from Huffington Post:

http://www.huffingtonpost.com/2015/04/26/chipotle-gmo-free-food_n_7149040.html

National Geographic. (2011, Apr 05). Oil-Eating Bacteria Engineered. Retrieved from National Geographic: http://news.nationalgeographic.com/news/2011/04/110405-nsf-oil-somasundaranvideo/ 
Ormandy, E. H., Dale, J., \& Griffin, G. (2011). Genetic engineering of animals: Ethical issues, including welfare concerns. Canadian Veterinary Journal, 544-550.

Palmer, R. (2013, Mar 30). GMO Health Risks: What The Scientific Evidence Says. Retrieved from International Business Times: http://www.ibtimes.com/gmo-health-risks-what-scientificevidence-says-1161099

Profita, C. (2012, Oct 26). Which Is Greener: Grass-Fed Or Grain-Fed Beef? Retrieved from Agriculture | Ecotrope: http://www.opb.org/news/blog/ecotrope/which-is-greener-grass-fed-or-grain-fed-beef/

UNICEF. (2015). THE REALITY OF MALARIA. NYC: UNICEF.

University at Buffalo. "From skin to brain: Stem cells without genetic modification: Study yields neural crest cells from adult skin cells, and could lead to new treatments for Parkinson's and other brain illnesses." ScienceDaily. ScienceDaily, 15 March 2017.

$<$ www.sciencedaily.com/releases/2017/03/170315125631.htm>

US Department of Agriculture. (2015). Percentage of genetically modified crops in the U.S. in 1997 and 2015, by type (as percent of total acreage). Washington, D.C.: US Department of Agriculture

VFA - Statistics. (2011). Number of patent applications for genetically engineered drugs worldwide in 1990 and 2010. Berlin: VFA. 